\title{
Proximate, Phytochemical and Antioxidant Mineral Compositions of Four Different Brands of Tea
}

\author{
Ifemeje J. C. ${ }^{{ }^{*}}$, Ifemeje M. O ${ }^{1}$, Egbuna C. ${ }^{1,2}$, Olisah M. C. ${ }^{3}$ \\ ${ }^{1}$ Department of Biochemistry, Faculty of Natural Sciences, Chukwuemeka Odumegwu Ojukwu University, \\ Anambra State- 431124, Nigeria. \\ ${ }^{2}$ Nutritional Biochemistry and Toxicology Unit, World Bank Africa Centre of Excellence, Centre for Public \\ Health and Toxicological Research (ACE-PUTOR), University of Port-Harcourt, Rivers State, Nigeria. \\ ${ }^{3}$ Department of Medical Biochemistry, Faculty of Basic Medical Sciences, Chukwuemeka Odumegwu Ojukwu \\ University, Anambra State- 431124, Nigeria.
}

\section{* Corresponding Author email: jcifemeje@gmail.com}

Article History

Received: 27 November 2019

Revised: 02 December 2019

Accepted: 11 January 2020

Published: 01 February 2020

Student(s)

- $\quad$ Ifemeje M.O

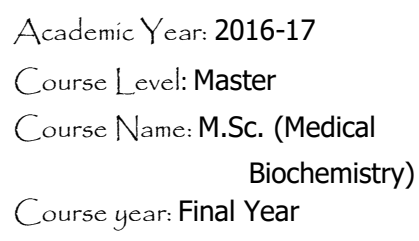

$\operatorname{Mentor}(s)$

- $\quad$ Ifemeje J. C.

\section{A BS T RA C T}

The comparative studies of the proximate, phytochemical and antioxidant mineral compositions of four different brands of green tea were investigated. The four different brands, Tianshi ${ }^{\circledR}$, Qualitea $^{\circledR}$, Slimfit ${ }^{\circledR}$, and Xiang $^{\circledR}$ were purchased from a supermarket in Ihiala Local Government Area of Anambra State, Nigeria. The samples were pulverized and stored in an airtight container prior to analysis. The proximate composition was analysed using AOAC method while phytochemical compositions of the green teas were investigated using standard methods. The result of the study indicated that the moisture content $(15.80 \pm 0.01 \%)$ and protein content $(1.05 \pm 0.00 \%)$ of Qualitea ${ }^{\circledR}$ was significantly higher $(\mathrm{P}<0.05)$ compared to Slimfit and Xiang tea while the fibre content of Xiang tea $(80.35 \pm 0.03 \%)$ was significantly higher $(\mathrm{P}<0.05)$ than other tea studied. The phytochemical study showed the presence of flavonoids, tannins, alkaloids, saponins and cardiac glycosides in all the teas studied. However, Qualitea ${ }^{\circledR}$ contains the highest amount of phytochemicals when compared to the other brands of tea investigated. Data obtained from the antioxidant mineral study showed that the four brands of the tea are good sources of antioxidant minerals such as $\mathrm{Fe}, \mathrm{Zn}, \mathrm{Cu}, \mathrm{Mn}$ and $\mathrm{Se}$. It is therefore recommended that tea be included in our menu because of their nutritive and health benefits.

Keywords: Green tea, Phytochemicals, proximate composition, saponins, glycosides.

\section{Introduction}

The consumption of tea has increased all over the world in recent decades and it has gained significant population [1]. Fermented and non-fermented teas are among the most widely consumed beverages in the world. They are reported to contain polyphenolic compounds which helps to prevent free radical - induced diseases [2]. It is usually made from the leaf of plant Camelia sinensis [3] and exerts most of its benefits 
through water-soluble antioxidant polyphenols notably a catechin, precisely epigallocatechin-3-gallate, which is believed to be responsible for most of the health benefits linked to green tea [4]. There are different types and quality of tea taken by different countries and races. Black (fermented) tea are produced when tea leaves are wilted, bruised rolled and fully oxidized, It contains much lower concentrations of polyphenols than green tea [5], and the extended oxidation of black tea increases the concentrations of the arubigins and the aflavins, which are two types of complex polyphenols [4]. Black tea contains the highest concentration of caffeine ranging from 654 to $112 \mathrm{mg}$ per $8 \mathrm{floz}$ serving [4] this tea is mostly taken in the west. Oolong tea is made from wilted, bruised, and partially oxidized leaves, creating an intermediate kind of tea. Oolong tea contains a mixture of simple polyphenols, such as catechins, and complex polyphenols [5]. The caffeine content of Oolong tea is higher than that of green tea ranging about 29 to $53 \mathrm{mg}$ per 8 floz serving and is commonly taken in Taiwan and China [6]. Green tea is made from unfermented leaves that are not oxidized and reportedly contains the highest concentration of powerful antioxidants called polyphenols. It contains the less amount of caffeine ranging from 24 to $39 \mathrm{mg}$ per 8 floz serving and is notably consumed in China, North Africa and Japan [5, 7]. Tea polyphenol prevents oxygen free radicalinduced hepatocyte toxicity through the inhibition of inducible nitric oxide synthase and toxin-induced liver oxidative DNA damage [5]. Green tea inhibition of lipid peroxidation in the kidney, liver and testes of pretreated animals as well as superoxide dismutase and catalase activities has been reported by Soussi et al. [8]. Several brands of teas are currently consumed by many Nigerians. None of much-admired health benefits and composition of these teas have been evaluated using comparative studies. Studies assessing qualitative and quantitative contents of brands of teas are scarce. This study was aimed at comparing the phytochemical, proximate and antioxidant mineral compositions of four brands of selected tea with a view of elucidating their nutritive and health benefit to man.

\section{Materials and Methods}

\subsection{Sample Collection}

The four selected brands of tea $\left(\right.$ Tianshi $^{\circledR}$, Qualitea ${ }^{\circledR}$, Slimfit ${ }^{\circledR}$, and Xiang $\left.{ }^{\circledR}\right)$ were purchased from superstores in Ihiala in Anambra state Nigeria and were stored in an airtight container at room temperature in the laboratory prior to analysis.

\subsection{Phytochemical Analysis}

Some phytochemical constituents like flavonoids, phenolic, saponins, tannins etc were investigated using aqueous extract of the samples. About $20 \mathrm{~g}$ of each sample was taken from the teabags and ground to a fine powder, the ground samples were extracted with water using soxhlet extractor until the complete extraction had taken place. The extracts were then evaporated to dryness using rotary evaporator [8]. Preliminary phytochemical screenings were done according to the methods described by [9-14].

\subsection{Proximate Analysis}

Proximate composition analysis was carried by the methods of AOAC [15]. Moisture content was determined by air oven drying. Fat content was by Soxhlet fat extraction method. Crude protein was determined using Micro Kjeldahl method. Crude fibre was determined by hydrolysis while ash content was by muffle furnace.

\subsection{Determination of Antioxidant Mineral Composition}

Antioxidant mineral composition was done using atomic absorption spectrophotometer method as described by Ezeonu et al [16] two grams of the ground food sample was weighed into a $25 \mathrm{ml}$ conical flask and $15.0 \mathrm{ml}$ digestion mixture was of perchlorie/nitric acid in the ratio of $1.2 \mathrm{v} / \mathrm{v}$ added. The resulting mixture was swirled and kept in the fume cupboard overnight. This was later digested at temperature of $150^{\circ} \mathrm{C}$ on a hot plate for 25 mins or until frothing ceases. At the end of the frothing, the samples were removed from the hot plate and boiled for 10 minmutes after which $3.0 \mathrm{mls}$ of hydrochloric acid was added 
Ifemeje et al., Adv. J. Grad. Res.; Vol. 8, Issue 1, pp: 1-7, July 2020

and further digestion carried out for 30 mins. The boiling tube was then removed from the hot plate and allowed to cool, and the content of the tube was made up to $50.0 \mathrm{mls}$ with deionized water and transferred into a universal bottle. The resulting solutions were then analyzed with Atomic Absorption Spectrophotometer (FS 240).

\subsection{Data Analysis}

Results generated from the study were expressed as mean \pm standard deviation of three replicate determinations. Statistical analysis was performed on the data using one-way analysis of variance (ANOVA) using statistical package for social sciences (SPSS) software version 18.0 and differences in means were compared by the Duncan's multiple range test. Significance was accepted at $\mathrm{P} \leq 0.05$.

\section{Results and Discussion}

\subsection{Contents of Phytochemical Compounds}

The result of phytochemicals screening (Table 1) showed that flavonoid was moderately and highly present in quali tea and slimfit tea respectively while saponins and cardiac glycosides were highly present in slimfit tea; the rest of the phytochemicals tested were slightly present. Tea contains high concentration of antioxidants called polyphenols. This is believed to be responsible for most of the health benefits linked to tea. These phytochemicals work in a number of ways which differ from one another depending on the functional group present in the chemical. Some are effective as free radical scavengers, while some have antibacterial, antiviral, antifungal, anti-inflammatory activities. Notably among the phytochemicals present in the four brands of tea studied are saponins, tannins, alkaloids, flavonoids and cardiac glycosides.

Table 1: Qualitative screening of phytochemicals of four Different Brands of Tea

\begin{tabular}{|l|l|l|l|l|l|}
\hline Phytochemical & Type of test & Tianshi & Xiang & Slimfit tea & Quali tea \\
\hline Flavonoids & Alkaline & + & + & ++ & +++ \\
\hline Tannins & Lead acetate & + & + & + & ++ \\
\hline Alkaloids & Hager's & + & + & + & + \\
\hline Saponins & Foam & + & + & ++ & + \\
\hline Cardiac glycosides & Killer-killani & + & + & +++ & + \\
\hline
\end{tabular}

Key: ---, not present, + present at low concentration, ++ Present at moderate concentration, +++ present at high concentration.

The phytochemicals identified in studied teas are similar to those previously reported in herbal teas by Orimadegun et al. [17]. The phytochemical content of Slimfit tea is comparable to the black tea reported by Mandal et al. [18]. The result of quantitative analysis of phytochemical showed that saponin and tannin content of quali tea were significantly higher $(\mathrm{p}<0.05)$ than that of slimfit tea followed by tianshi and xiang (Fig. 1). The presence of saponins in tea may help reduce blood pressure and cholesterol level in blood by preventing excessive intestinal absorption of cholesterol and thus reduce the risk of cardiovascular disease such as hypertension [2, 19].

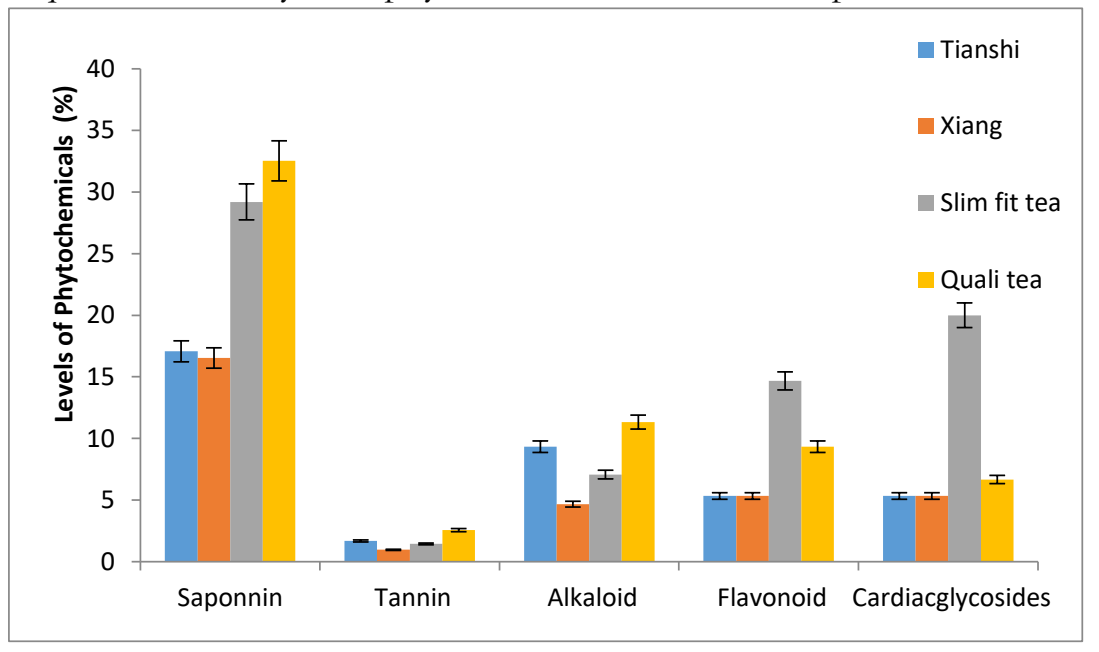

Figure 1: Phytochemical composition of four different brands of green tea. 
Tannins have antidiarrhoeal, anti-dysentry, anti-septic, antiviral, antifungal, antiparasitic and antiirritant properties and useful in curbing haemorrhage, in wound healing and improving vascular health by suppressing peptide that harden arteries [20]. Tannins also have antimicrobial activities which could be as a result of metal deposition/complexation, hydrogen binding or specific interactions with vital proteins such as enzymes in microbial cells [21].

The flavonoid and cardiacglycosides content of Slimfit tea was significantly higher $(\mathrm{p} \leq 0.05)$ followed by Quali, Tianshi and Xiang tea was the least (Fig. 1). Flavonoids have been reported to constitute a wide range of substances that play important role in protecting biological system against the harmful effect of oxidative processes on macromolecules such as carbohydrate, proteins, lipids and DNA [22], while the presence of cardiac glycosides in teas studied could account for their cardioactive properties. Cardiac glycosides are used in treatment of congestive heart failure and cardiac arrhythmia whereby they inhibit $\mathrm{Na}^{+} / \mathrm{K}^{+}$-ATPase pump that causes positive ionotropic effects and electrophysiological changes [23-25]. This strengthens the heart muscles and the power of systolic concentration against congestive heart failure. Alkaloid was significantly highest in quali tea followed by tianshi and the least was xiang. Alkaloids are known to have a powerful effect on animal physiology and play some metabolic roles and control development in living systems [26-28]. It is also employed in treatment of high blood pressure as it dilates the blood vessels. Other pharmarcological effect of alkaloids includes antimalarial activities, anticancer and antiarrhythmic effect [22, 29, 30].

\subsection{Proximate Composition}

Result of proximate composition of moisture and protein content of Qualitea were significantly high $(\mathrm{p}<0.05)$ than Slimfit and Xiang (Table 2). Ash content of tea studied was in the order Slimfit $>$ Tianshi $>$ Xiang $>$ Qualitea. Fat content of Tianshi was significantly high $(\mathrm{p}<0.05)$ compared with other samples studied while fibre content of Xiang and Tianshi did not differ significantly $(p>0.05)$ but were significantly higher $(\mathrm{p}<0.05)$ than Quali tea and Slimfit tea (Table 2). The significant variation in proximate composition of samples studied indicated that the samples possess comparative advantage over one another. The moisture content of the studied samples was similar to the findings of Akande et al. [7] but in variance with report of Muhammed et al. [31]. Moisture content of tea is an essential parameter of quality [32]. The moisture contents of the samples studied were above proposed value of $6.5 \%$ [31] and this may have a negative implication on the shelf life of the samples. The protein contents of the samples were in accordance with the report of Rehman et al. [33] who suggested 1-2\% of protein and $0.95-1.62 \%$ of fat for better quality of tea samples. However, the fat content of the samples studied were above the suggested values. The ash content of the samples studied ranged from1.00-2.50\%. This is in line with Rehman et al. [33] who proposed that ash content should not exceed 5.54\% in order to maintain quality of tea during storage. The crude fibre content in all the samples were high and in variance to report of Muhammed et al. [31]. The fibre content of all the samples studied were higher than $16.5 \%$ proposed by Venkatesan $e t$ al. [34] for maintenance of high-quality tea during storage.

Table 2: Proximate Composition of Four Different Brands of Tea

\begin{tabular}{|l|l|l|l|l|}
\hline Parameters (\%) & Tianshi & Qualitea & Slimfit tea & Xiang tea \\
\hline Moisture & $14.51 \pm 0.01^{\mathrm{b}}$ & $15.80 \pm 0.01^{\mathrm{a}}$ & $12.90 \pm 0.00^{\mathrm{d}}$ & $13.20 \pm 0.01^{\mathrm{c}}$ \\
\hline Protein & $1.05 \pm 0.01^{\mathrm{a}}$ & $1.06 \pm 0.00^{\mathrm{a}}$ & $0.80 \pm 0.00^{\mathrm{b}}$ & $0.30 \pm 0.01^{\mathrm{c}}$ \\
\hline Ash & $2.016 \mathrm{t} \pm 0.01^{\mathrm{b}}$ & $1.00 \pm 0.01^{\mathrm{d}}$ & $2.50 \pm 0.01^{\mathrm{a}}$ & $1.80 \pm 0.01^{\mathrm{c}}$ \\
\hline Fat & $5.80 \pm 0.01^{\mathrm{a}}$ & $4.14 \pm 0.02^{\mathrm{c}}$ & $3.60 \pm 0.02^{\mathrm{d}}$ & $4.35 \pm 0.03^{\mathrm{b}}$ \\
\hline Fibre & $76.63 \pm 0.01^{\mathrm{a}}$ & $78.00 \pm 0.01^{\mathrm{c}}$ & $80.20 \pm 0.02^{\mathrm{b}}$ & $80.35 \pm 0.03^{\mathrm{a}}$ \\
\hline
\end{tabular}

Values are mean \pm standard deviation of triplicate determinations

Values in the same row bearing the same superscript letter are not significantly different at $\mathrm{p}<0.05$. 


\subsection{Antioxidant Mineral Composition}

The result of antioxidant mineral compositions $(\mathrm{mg} / \mathrm{g}$ ) of four brands of green tea studied (Fig. 2) showed the presence of $\mathrm{Mn}, \mathrm{Zn}, \mathrm{Se}$, and Fe in all the green tea. This indicated that green teas are good sources of antioxidant minerals. Antioxidants are molecules that inhibit the oxidation of other molecules. Green tea contains many antioxidant components which help scavenge free radicals especially superoxide anions and may thereby protect cells from oxidative stress.

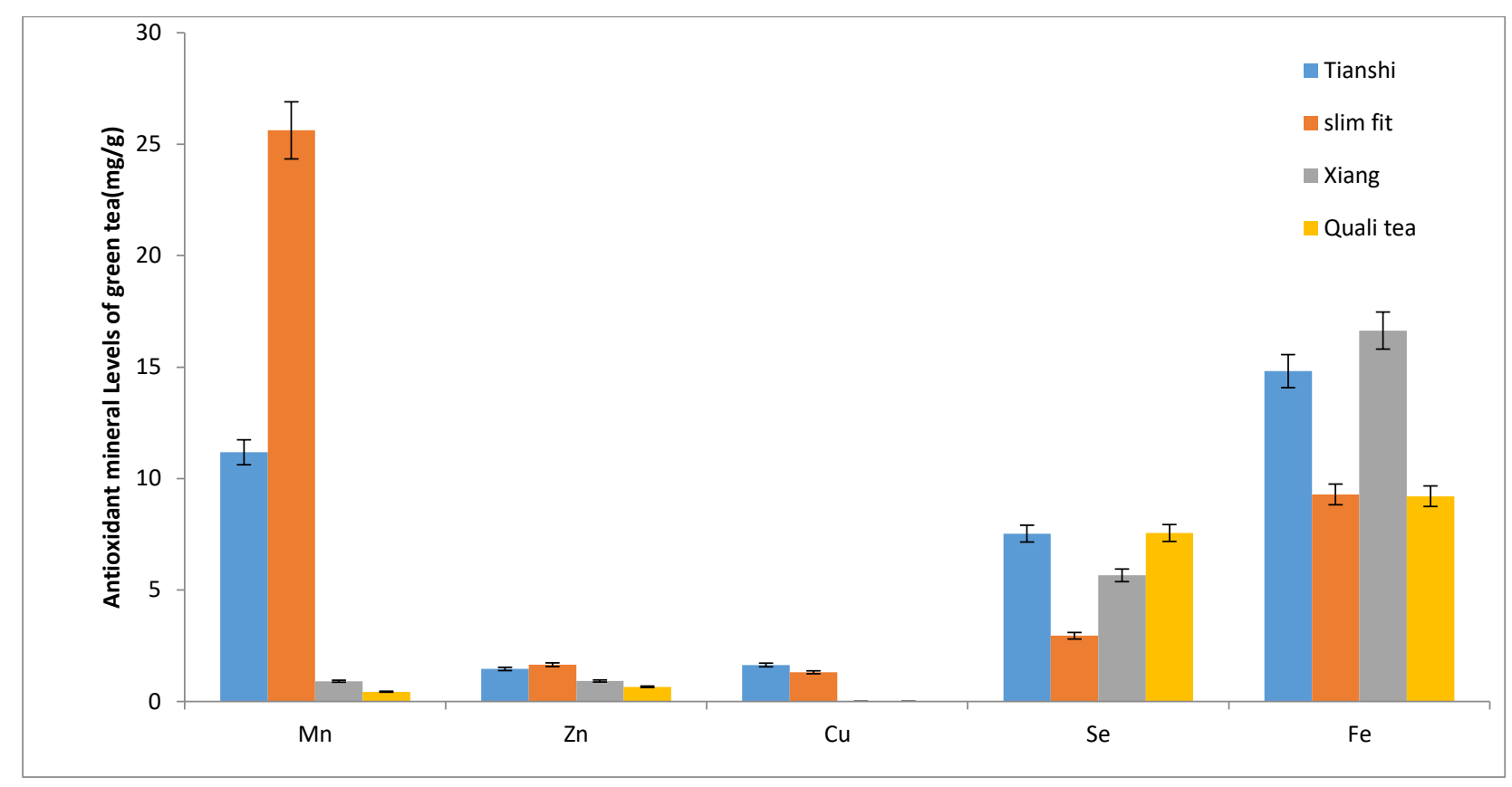

Figure 2: Antioxidant mineral composition of four different brands of green tea.

The concentration of $\mathrm{Mn}(25.62 \pm 0.02 \mathrm{mg} / \mathrm{g})$ and $\mathrm{Zn}(1.65 \pm 0.02 \mathrm{mg} / \mathrm{g})$ in Slimfit tea were significantly higher $(\mathrm{p}<0.05)$ than the levels in Tianshi $(11.18 \pm 0.02 \mathrm{mg} / \mathrm{g})$ and $(1.46 \pm 0.02 \mathrm{mg} / \mathrm{g})$; and Xiang tea $(0.91 \pm 0.02 \mathrm{mg} / \mathrm{g})$ and $(0.92 \pm 0.02 \mathrm{mg} / \mathrm{g})$ respectively, while the least values were found in Quali tea.

The copper level was highest in Tianshi tea followed by Slimfit tea and was below detectable level in Xiang tea and Quali tea. The mean value of minerals in the four different brands of green tea studied were in the order of Slimfit $>$ Tianshi $>$ Xiang tea $>$ Quali tea and differences in the levels of antioxidant minerals could be attributable to specie differences, differences in processing method prior to packaging, changes in climatic condition and soil properties. The order of antioxidant activity observed for the four studies teas is similar to antioxidant activity of green, oolong, back and $\mathrm{Pu}$-er teas (green $>$ oolong $>$ black $>\mathrm{Pu}$-erh tea) reported by Yashin et al., [35].

Zinc plays both catalytic and structural role in enzyme activity. It is an antioxidant capable of protecting cells from the damaging effects of oxygen radicals released during lymphocyte activation. Its deficiency impairs immunity and decreases resistance to infectious diseases. While copper is a constituent of cytochrome $\mathrm{C}$ oxidase it directly participates in the transfer of electron from reduced cytochrome $\mathrm{C}$ to molecular oxygen. Inadequate supply of copper decreases the enzyme activity and hence affects oxidative phosphorylation in a number of tissues.

The level of selenium in Tianshi did not differ significantly $(\mathrm{p}>0.05)$ with qualitea but was significantly higher $(\mathrm{P}<0.05)$ than xiang tea and Slimfit tea while the Fe level was highest in Xiang tea followed by Tianshi tea and was least in Quali tea. The high level of selenium in tianshi and slimfit treated rats as observed from the study could be attributed to differences in composition of the green tea. Selenium appears in plant as selenomethionine (Barbara and Robert, 2001). It is a catalytic component of enzymes or proteins such as glutathione peroxidase, thus playing a role in protecting against oxidative damage to 
erythrocytes. Selenium deficiency in human is known as Kasham disease characterised by cardiomyopathy [36].

\section{Conclusion}

Teas are plant-based products that represent a source of bioactive natural substances and compounds. The study has shown that the four brands of tea evaluated are good sources of phytochemical and antioxidant minerals however quali tea and Xiang has an age over other teas studied in terms of their phytochemical contents. Tea studied has comparative advantage over one another in terms of their antioxidant mineral compositions and may enhance antioxidant system of the body. Data available from this study will help guide consumers when making their choice for tea. Similar studies should be extended to other tea brands consuming in our country. Considering the beneficial contributions of these teas on health, further researches are needed to isolate, purify and identify all the phytochemical components of these teas in order to appreciate and explain the true extent of their effects. Further studies should also focus on determining the antioxidant activity in studies teas by using different mechanisms such as total Phenolic content determination, Scavenging of Hydrogen Peroxide, Reducing power assay and Ferrous Ion Chelating Activity.

\section{Competing Interests}

Authors declared that no conflict of interest exist.

\section{How to Cite this Article:}

J. Ifemeje, M. Ifemeje, C. Egbuna, and M. Olisah, "Proximate, Phytochemical and Antioxidant Mineral Compositions of Four Different Brands of Tea”, Adv. J. Grad. Res., vol. 8, no. 1, pp. 1-7, Jan. 2020. doi: 10.21467/ajgr.8.1.1-7

\section{References}

[1] M. Miri, A. Bhatnagar, Y. Mahdavi, L. Basiri, A. Nakhaei, R. Khosravi, et al., "Probabilistic risk assessment of exposure to fluoride in most consumed brands of tea in the Middle East", Food and Chemical Toxicology, vol. 115, pp. 267-72, March 2018.

[2] F.O. Ujah, "Medicinal Potential of Green Tea", in: Phytochemistry, Volume 2: Pharmacognosy, Nanomedicine, and Contemporary Issues, C. Egbuna, et al., Eds. New York: Apple Academic Press, 2019, pp. 3-15.

[3] A. Jigisha, N. Rai, N. Kumar, and P. Gaututam, "Green tea: A magical herb with miraculous out comes," International Research Journal of Pharmacy, vol. 38, pp. 112-5, May 2012.

[4] V. R. Sinija, and H. N. Mishra, "Green tea: health benefits," Journal of Nutritional and Environmental Medicine, vol. 17, no. 4 pp. 232-42, December 2008.

[5] N. Ogle, "Green tea Camellia sinensis," Australian Journal of Medical Herbalism, vol. 21, no. 2, pp. 44-8, January 2009.

[6] E. P. Sánchez, E. R. V. Marcel, and C. R. G. Juan, "Hepatotoxicity due to green tea consumption (Camellia Sinensis): A review”, Rev Col Gastroenterol, vol. 28, pp. 43-9, December 2012.

[7] I. S. Akande, T. A. Samuel, U. Agbazue, and B. L. Olowolagba, "Comparative proximate Analysis of ethanolic and water extracts of Cymbopogon citratus (Lemon grass) and four tea brands", Plant Sciences Research, vol. 3 no. 4, pp. 29-35, 2011.

[8] A. Soussi, F. Croute, J. P. Soleihavoup, A. Kammoun, and A. El-feki, "Impact of green tea on oxidative exposure in male rats", C.R Biol, Vol. 329, no. 10, pp. 775-84, October 2006.

[9] A. Sofowora, Medicinal Plant and Traditional Medicine in Africa. $2^{\text {nd }}$ ed. Spectrum Books Limited, Ibadan, Nigeria, 1993.

[10] J. Harborne, Phytochemical Methods, Chapman and hall, ltd, London, 1973, pp. $49-118$.

[11] C. Egbuna, J. C. Ifemeje, M. C. Maduako, H. Tijjani, S. C. Udedi, A. C. Nwaka, and O. M. Ifemeje, "Phytochemical Test Methods: Qualitative, Quantitative and Proximate Analysis", in: Phytochemistry, volume 1: Fundamentals, Methods, and Applications. C. Egbuna, et al., Eds. New York: Apple Academic Press, 2018, pp. 381-425.

[12] H. Edeoga, D. Okwu, and B. Mbabie, "Phytochemical constituent of some Nigeria medicinal plants", African Journal of Biotechnology, vol. 4, no. 7, pp. 685 - 8. February 2005.

[13] J. C. Ifemeje, C. Egbuna, J. O. Eziokwudiaso, and F. C. Ezebuo, "Determination of the Anti-nutrient Composition of Ocimum gratissimum, Corchorus olitorius, Murraya koenigii Spreng and Cucurbita maxima", International Journal of Innovation and Scientific Research, vol. 3, no. 2, pp. 127-33, June 2014.

[14] J. C. Ifemeje, J. T. Gbolakoro, C. Egbuna, and V. N. Arazu, "Comparative Studies on In vitro Antioxidant Properties and Free Radical Scavenging Capacity of Methanolic Extracts of Annona muricata and Citrus maxima Leaves", Tropical Journal of Applied Natural Sciences, vol. 2, no. 2, pp. 132-6, March 2018.

[15] AOAC, Official methods of analysis. $17^{\text {th }}$ Ed. Association of Analytical chemist, Horowitz Maryland, 2000, pp. 12-20.

[16] F. C. Ezeonu, M. J. Amanabo, S. C. Udedi, and O. C. Edeogu, "Iron and zinc status in soils, water and staple food cultivars in Itakpe Kogi State of Nigeria", Environmentalis, vol. 22, no. 3, pp. 237-40, September 2002. 
Ifemeje et al., Adv. J. Grad. Res.; Vol. 8, Issue 1, pp: 1-7, July 2020

[17] B. E. Orimadegun, E. B. Bolajoko, A. A. Onyeaghala. and O. O. Ademola-Aremu, "Quantitative analyses of phytochemical and trace elements contents of daily detox, herbal tea consumed in Nigeria", Journal of Medicinal Plants Research, Vol. 12, no. 20, pp. 28995, July 2018.

[18] S. Mandal, A. Samanta, A. Patra, S. Pradhan, S. Roy, K. Das, et al., "A comparative assessment of phytochemical screening, antioxidant and antimicrobial activities between leaf and dust of black tea extracts", Int. J. Res. Ayurveda Pharm, vol. 7, no. 6, pp. 90-5, December 2016.

[19] D. Krishnaiah, T. Devi, A. Bono, and R. Sarbatly, "Studies on phytochemical constituents of six Malaysian medicinal plants", Journal of Medicinal Plants Research, vol. 3, no. 2, pp. 67-72, February 2009.

[20] O. A. Awoyinka, I. O Balogun, and A. A. Ogunnowo, "Phytochemical screening and invitro bioactivity of Cnidoscolus aconitifolius (Euphorbiaceae)", Journal of Medicinal Plants Research, vol. 1, no. 3, pp. 63-5, September 2007.

[21] H. Schroeter, C. Heiss. J. Balzer, P. Kleinbongard, C. L. Keen, N. K. Hollenberg, et al., “(-)-Epicatechin mediates beneficial effects of flavanol-rich cocoa on vascular function in humans", Proc. Natl. Acad. Sci. vol. 103, no. 4, pp. 1024-9, February 2006.

[22] S. Mamta, S. Jyoti, N. Rajeev, S. Dharmendra, and G. Abhishek, "Phytochemistry of Medicinal Plants", Journal of Pharmacognosy and Phytochemistry, vol. 1, no. 6, pp. 168-182, 2013.

[23] J.C. Ifemeje, C. Egbuna, J. O. Eziokwudiaso, and F. C. Ezebuo, "Determination of the Anti-nutrient Composition of Ocimum gratissimum, Corchorus olitorius, Murraya koenigii Spreng and Cucurbita maxima”, Intl. J. Inno. Sci. Res., vol. 3, no. 2, pp. 127-33, June 2014.

[24] C. Egbuna, and J. C. Ifemeje, "Biological Functions and Anti-nutritional Effects of Phytochemicals in Living System", IOSR Journal of Pharmacy and Biological Sciences (IOSR-JPBS), vol. 10, no. 2, pp.10-9, April 2015.

[25] S. N. Ngoci, C. M. Mwendia, and C. G. Mwaniki, "Phytochemical and cytotoxicity testing of Indigofera lupatana Baker F.", Journal of Animal \& Plant Sciences, vol. 11, no. 1, pp. 1364-73, 2011.

[26] C. Egbuna, J. C. Ifemeje, T. L. Kryeziu, M. Mukherjee, H. Shah, G. M. N. Rao, et al., "Introduction to phytochemistry", in: Phytochemistry, volume 1: Fundamentals, Methods, and Applications. C. Egbuna, et al., Eds. New York: Apple Academic Press, 2018, pp. 3-35.

[27] C. Egbuna, S. Kumar, S. M. Ezzat, J. C. Ifemeje, and K. Saravanan, Phytochemicals as Lead Compounds for New Drug Discovery. $1^{\text {st }}$ ed. USA: Elsevier, 2019.

[28] H. Tijjani, C. Egbuna, and D. C. Luka, "Biosynthesis of phytochemicals", In: Phytochemistry, volume 1: Fundamentals, Methods, and Applications, C. Egbuna, et al. Eds. New York: Apple Academic Press, 2018, pp. 37-78.

[29] S. M. Ezzat, J. Jeevanandam, C. Egbuna, S. Kumar, J. C. Ifemeje, "Phytochemicals as sources of drugs" in: Phytochemistry: in vitro and in silico updates. S. Kumar, and C Egbuna, Eds, Singapore: Springer Nature, 2019, pp. 3-22.

[30] K. Shashank, and C. Egbuna, Eds, Phytochemistry: In vitro and in silico updates. Singapore: Springer Nature, 2019.

[31] A. Muhammad, A. Asif, A. Anwaar, K. Nauman, H. Imran, and A. Iftikhar, "Chemical composition and sensory evaluation of tea (Camellia Sinensis) commercialized in Pakistan”, Pak. J. Bot., vol. 45, no. 3, pp. 901-7, May 2013.

[32] L. Yao, X. Liu, Y. Jiang, N. Caffin, B. D’Arcy, R. Singanusong, N. Datta, and Y. Xu, “Compositional analysis of teas from Australian supermarkets", Food Chem. Vol. 94, no. 1, pp. 115-22, January 2006.

[33] S.U. Rehman, K. Almas, N. Shahzadi, N. Bhatti, and A Saleem, "Effect of time and Temperature on infusion of tannins from commercial brands of tea", Int. J Agric.Biol., vol. 4, no. 2, pp. 285-7, March 2002.

[34] S. Venkatesan, V. K. Senthurpandian, S. Murugesan, W. Maibuam, and M. N. K. Ganapathy, "Quality standards of CTC black tea as influenced by sources potassium Fertilizer”, J. Sci. food Agric., vol. 86, no. 5, pp. 799-803, April 2006.

[35] A. Yashin, Y. Yashin, B. Nemzer, "Determination of Antioxidant Activity in Tea Extracts, and Their Total Antioxidant Content", American Journal of Biomedical Sciences, vol. 3, no. 4, pp. 322-35, September 2011.

[36] A. B. Barbara, M. R. and Robert, "Manganese", in: present knowledge in Nutrition, $8^{\text {th }}$ ed. International life science Institute ILSI press, 2001, pp. 388-98.

Publish your books with AIJR publisher-

$\checkmark \quad$ Publish with ISBN and DOI.

$\checkmark$ Publish Thesis/Dissertation as Monograph.

$\checkmark$ Publish Book Monograph.

$\checkmark$ Publish Edited Volume/ Book.

$\checkmark$ Publish Conference Proceedings

$\checkmark \quad$ Retain full copyright of your books.

Submit your manuscript at books.aijr.org
Publish your research article in AIJR journals-

$\checkmark \quad$ Online Submission and Tracking

$\checkmark$ Peer-Reviewed

$\checkmark$ Rapid decision

$\checkmark \quad$ Immediate Publication after acceptance

$\checkmark \quad$ Articles freely available online

$\checkmark$ Retain full copyright of your article.

Submit your article at journals.aijr.in 